\title{
ダブル塗エ中質紙の塗エプロセスの最適化
}

\author{
住友重機械バルメット(籼技術部森隆資
}

\section{Optimizing the coating process for double-coated, wood-containing papers}

\author{
Takashi Mori \\ Sumitomo Jukikai Valmet Ltd.
}

\begin{abstract}
Brightness, opacity, surface strength, ink density, and cracking tendency were not affected by the layout strategy for drying the precoat. Dryer capacity and economic aspects should be considered more than questions about quality in optimizing the precoating installation.
\end{abstract}

\section{1.はじめに}

過去数年間, 製紙業界の中質コート紙, 特に軽量コー 卜紙 (LWC) の全生産能力は大幅に增加した。同時に 競争上の圧力によってメーカはあらゆる中質系コート 紙に関し，一段と高い効率と高い品質を得るべく努力 を強いられるようになってきた。そのような中で，よ り費用のかかる上質コート紙に匹敵する印刷品質を得 る可能性のあることから，中量コート紙 (MWC) に対 する関心がたかまっている。

$\mathrm{MWC}$ 紙はヒート・セット・オフセット輪転機に最 適であり，オフセット印刷にも適していると考えられ る。MWC 紙を使用した代表的な印刷物には販売促進 資料, 高品質の宣伝および専門雑誌等が挙げられる。

2 層コートは当初, 高品質の板紙及び上質系コート 紙の生産用に使われていた。ごく最近では中質紙の印 刷品質を高めるために使用されている。

1 層コート紙では塗布層は直接, 粗い紙表面に塗工 される。2 層コート紙ではプレコートには通常低コス トの顔料を使用して紙の表面を被覆し，高品質のトッ プコート用として均一な下地を構成する。これによっ て一段と表面品質に優れインキ吸収度が均一なコート 層を得ることができる。

このテストではパイロットコータを用いて 2 層コー トの基本パラメータの最適化とこのプロセスで得られ る品質の把握を行った。

註） 本稿は 1990 年度フィンランド TAPPI 塗工会 議で発表された論文の要約である。

\section{2. テスト条件と手順}

1）原紙

テストでは $44 \mathrm{~g} / \mathrm{m}^{2}$ と $40 \mathrm{~g} / \mathrm{m}^{2}$ の 2 種類の原紙が 用いられた。両方とも兏分含有率は $6 \sim 8 \%$, クラフト パルプを 40 0 50\%, 残りは砕木パルプとした。原紙の 平滑度は 300 $400 \mathrm{ml} / \mathrm{min}$ (Bendtsen) で，水分は約 3\%であった。

2）パイロットコータ

テストは幅 $1 \mathrm{~m}$ のテストコータで実施された。ブ レード塗工部は 2 方式が使用できる。すなわち 1 つは ショートドウェル式, 他はアプリケータロール式が使 用できる。ショートドウェル式ではブレードはエヤー チューブでローディングされた。アプリケータロール 式では機械的にローディングされ，ブレード先端角は ローディングカとは無関係に一定に保たれた。

1 層塗工テストではスチレンブタジエン (SB) ラ テックスとカルボキシメチールセルロース (CMC) を バインダとしたクレーコーティングカラーが使用され た。2 層塗工テストではプレコート用として SB ラ テックスとスターチをバインダとした粗い炭酸カル シュームが用いられた。トップコート顔料としては $\mathrm{SB}$ ラテックス，ポリビニールアセテート $(\mathrm{PVAC})$ ラ テックス,および CMC をバインダとして, 細かい炭酸 カルシュームと若干のクレーを混ぜたカラーが使用さ れた。表 1 にコーティングカラーの詳細を示す。

ブレード後には最大 6 列の電気式 IR ドライヤと 4 列のガス IR ドライヤ，更にその後にはガス加熱エヤ フォイルドライヤ 4 列を使用し, 多様な条件下で塗工 
表 1 塗 料 配 合

\begin{tabular}{|c|c|c|c|}
\hline 配 & 割合 & $\begin{array}{l}\text { 固形分 } \\
\text { 含量\% }\end{array}$ & $\begin{array}{c}\text { 粘 度 } \\
\mathrm{cp}\end{array}$ \\
\hline 1 層塗工 & & 60.5 & $1,200 \sim 1,400$ \\
\hline SPS*クレー & 100 & & \\
\hline $80 \%<2 \mu \mathrm{m}$ & & & \\
\hline $85.5 \%$ 白色度 & & & \\
\hline SB ラテックス & 10 & & \\
\hline 中粘度 CMC & 0.8 & & \\
\hline 不溶化剂 & 0.5 & & \\
\hline 螢光増白剂 & 0.5 & & \\
\hline 2 層塗工, 下塗り & & $61 \sim 64$ & $200 \sim 900$ \\
\hline $\begin{array}{l}\text { 粗砕 } \mathrm{CaCO}_{3} \\
\quad 60 \%<2 \mu \mathrm{m}\end{array}$ & 100 & & \\
\hline SB ラテックス & 6 & & \\
\hline でんぷん & 6 & & \\
\hline 不溶化剂 & 0.4 & & \\
\hline 上 塗 ク & & 62 & $1,350 \sim 1,550$ \\
\hline $\mathrm{CaCO}_{3}$ & 70 & & \\
\hline $90 \%<2 \mu \mathrm{m}$ & & & \\
\hline 95\%白色度 & & & \\
\hline $\begin{array}{c}1 \text { ブラジルクレー } \\
\text { 87\%白色度 }\end{array}$ & 30 & & \\
\hline SB ラテックス & 6 & & \\
\hline PVAc ラテックス & 6 & & \\
\hline 中粘度 CMC & 1 & & \\
\hline 不溶化剂 & 0.6 & & \\
\hline 螢光増白剂 & 0.5 & & \\
\hline ステアリン酸塩 & 0.5 & & \\
\hline
\end{tabular}

* SPS はヨーロッパで最も一般的に使用される軽 量塗工用顔料の一つで, 英国のイングランド・チャ イナ・クレーから供給されたもの。

面の乾燥が行われた。運転速度は $1,050 \mathrm{~m} / \mathrm{min}$ から $1,200 \mathrm{~m} / \mathrm{min}$ までの範囲で変化させた。中間段階では 水分は $3.5 \%$ 以下に押之，最終水分は塗工量に応じて $4.5 \%$ から $6.0 \%$ の間で調節した。

3）仕上げ用カレンダー加エ

コートされた紙は 12 段のスーパーカレンダを用い て, 硬度 85 ショアDのコットンロールを使用し, 310 $\mathrm{kN} / \mathrm{m}$ 以下の線圧をかけ, 運転速度 $500 \mathrm{~m} / \mathrm{min}$ でス一 パー掛けされた。スーパー後の紙の水分は 2 層コート 紙で 3.0 4.0\%1 層コート紙で 4.0 ～ $5.0 \%$ であった。

\section{4）印刷}

塗工後スーパーカレンダー加工されたテスト紙は ヒートセットオフセット輪転機で印刷された。黑・青・
紫紅・黄色の順序でヒートセットカラー 4 色を使用し た。運転速度は $236 / \mathrm{min}$, しめし水の $\mathrm{pH}$ は 5.0 , イソ プロパノール含有量は $12 \%$ であった。乾燥フード内の 温度は $160^{\circ} \mathrm{C}$, 紙匹出口温度は約 $130^{\circ} \mathrm{C}$ であった。

\section{5）紙の分析}

塗工量はコート紙と非コート紙（又はコート紙及び プレコート紙）間のアッシュ含有量の差で決定した。 塗工量はX線蛍光を用いてオンラインで測定し，水分 は赤外線を用いてオンラインで測定した。

Bendtsen 平滑度はSCAN-P 21：67 に従って決定 し, パーカープリントサーフ平滑度は $10 \mathrm{~kg} / \mathrm{cm}^{2}$ (S 10）で測定し，ハンター光沢值は角度 $75^{\circ}$ で測定した。 塗層割れの傾向はフィンランド紙パルプ研究所が中質 ヒートセットオフセット紙用として確立した方法に 従って測定した。調湿済の紙を $300^{\circ} \mathrm{C} て ゙ 1.5$ 秒間乾燥 した後，直ちにテストカレンダで流れ方向に線圧 4.6 $\mathrm{kN} / \mathrm{m}$ で折りたたんだ。折たたんだ紙の引張り強さは SCAN-P 38：80に従って测定した。

ウエットピック強度は乾燥した試料との比較によっ て決定した。塗工試料の表面を加湿し Huberのピッキ ングインキにより Prufbau で印刷を行い, 乾燥した試 料も同一条件で印刷した後，両試料のインキ濃度を測 定してウェットピック強度の計算を行った。低い数値 が耐水性が優れていることを示す。

ヒート・セット印刷された各種試料について肉眼で 比較を行い, 見た目の美しさと均一性について判定を 行った。不透明度と白色度はSCAN 法にしたがって判 定した。流れ方向表面強さはIGT, ISO 3762 によって 判定した。

\section{1 層塗エ, プレコート及びトップコート塗エ 量が紙の特性に与える影響}

\section{1） 2 層塗工と 1 層塗工の比較}

$40 \mathrm{~g} / \mathrm{m}^{2}$ の原紙に 1 層塗工した紙を他の 2 枚の紙と の比較を行った。

他の紙とは@同一原紙に同一塗工量で 2 層塗工した 紙及び，(D) $44 \mathrm{~g} / \mathrm{m}^{2}$ の重い原紙に 2 層塗工で塗工量を 増やした紙である。2 層塗工用の塗料は 1 層塗工で使 用したものより安価であった。3 種類の紙のすべての 特性を表 2 に記載する。結果は以下の通りである。 総塗工重量が同じである場合，2 層塗工紙は印刷後 も平滑度は変らなかったが, 1 層塗工紙は緎維が膨潤 した結果，面が粗くなった。印刷光沢は 2 層塗工した 方が優れている。2 層塗工紙の塗工量が増加すると, 印刷前後の品質が全体的に向上する。

この他，同じ原紙に塗工した場合，2層塗工をする 
表 21 層塗工紙と 2 層塗工紙の品質比較 1 層塗工 2 層塗工 2 層塗工

\begin{tabular}{|c|c|c|c|}
\hline 坪 量 $\mathrm{g} / \mathrm{m}^{2}$ & 40 & 40 & 44 \\
\hline \multicolumn{4}{|l|}{ 塗 工 量 $\mathrm{g} / \mathrm{m}^{2}$} \\
\hline トップ側 & 11.9 & 6 & 8 \\
\hline ボトム側 & - & 6 & 8 \\
\hline \multicolumn{4}{|l|}{ 印 刷 前 } \\
\hline 白色度 \% & 74 & 74 & 75 \\
\hline 不透明度 \% & 94 & 93 & 95 \\
\hline 平 滑 度* $\mathrm{ml} /$ 分 & 17 & 12 & 11 \\
\hline 紙 光 沢 \% & 59 & 62 & 66 \\
\hline \multicolumn{4}{|l|}{ 印 刷 後 } \\
\hline 平 滑 度* $\mathrm{ml} /$ 分 & 22 & 10 & 10 \\
\hline $\begin{array}{l}\text { 平 滑 度* } \mathrm{ml} / \text { 分 } \\
\text { (画線部) }\end{array}$ & 25 & 12 & 12 \\
\hline $\begin{array}{l}\text { 印刷後の光沢 \% } \\
(4 \text { 色) }\end{array}$ & 82 & 85 & 87 \\
\hline
\end{tabular}

* Bendtsen

と 1 層塗工に比べて, 総塗工量が少ない場合でも緎維 被覆性と平滑度は 1 層塗工の結果を上回ることが判明 した。プレコートに低コストの顔料を使用しトップ コートで塗工品質を最適化すれば良いので 1 層塗工紙 よりも安くなる。更に印刷用インキは主として 2 層塗 工紙の表層に吸着されるので，インキの必要量が少な くてすみ, 緎維膨潤も少なくなり印刷機で穏やかに乾 燥することが出来る。実機規模の設備では, 紙の湿潤 と乾燥の回数が倍になることによる紙強度の低下（伸 び率の低下）及び 2 基のかわりに 4 基のコーティング
ヘッドを備えることによる生産効率の低下と上記各利 点の得失を評価すべきであろう。

2）トップコートとプレコートの塗エ比率が与える 影響

トップコート塗工量は 5.0 から $13.5 \mathrm{~g} / \mathrm{m}^{2}$ の範囲, プレコートは 6.5 から $12 \mathrm{~g} / \mathrm{m}^{2}$ の範囲で変えてテス トした。紙品質の評価はこれらの範囲全般で行った。 結果の一部を表 3 に示す。

2 層塗工紙の紙特性は, 主としてトップコートに よって決まり, プレコート層はトップコート用として 均一な下地を作る役割を果なす。総塗工量を一定とす るとトップコートが多いほど光沢，平滑度などの特性 は改善されたが, 総塗工量が少ない場合にはこの改善 は見られなかった。

トップコート塗工量が増えるとウエットピック傾向 が減少し，プレコート量に対するトップコート量の割 合が増加すると見た目と表面の均一性が向上する。こ れらの改善対策をやるかどうかについては，トップ コートの材料費増加額とよく比較検討する必要がある。 実機では乾燥能力又は塗工プロファイルを維持する上 から, 使用可能な塗工量は限定されるものと考えられ る。

図 1 に示す通り，プレコート量に対するトップコー ト量の割合が増加すると（特に総塗工量が多くなる と), 塗層割れの傾向(折った紙の引張り強さとして測 定）は増加した。しかし塗層割れの傾向に最も影響し たのは,やはり総塗工量であった。MWC 紙は繊維に 対する塗工割合が高いので, 実際の生産段階では塗層 割れの傾向を注意深くモニターする必要があろう。

表 3 トップコート量とプレコート量の比, 総塗工量, 塗工方法が印刷特性に与える影響

\begin{tabular}{|c|c|c|c|c|}
\hline $\begin{array}{l}\text { トップコート量と } \\
\text { プレコート量の比 }\end{array}$ & 光 ${ }^{\text {沢 }}$ & $\begin{array}{c}\text { 平 滑 度 } \\
\text { PPS }\end{array}$ & $\begin{array}{c}\text { ウエットピック } \\
\%\end{array}$ & 目視評価* \\
\hline & \multicolumn{3}{|c|}{ アプリケータロール下塗り, 総塗工量 $22 \mathrm{~g} / \mathrm{m}^{2}$} & \\
\hline 0.84 & 58.4 & 1.23 & 0.73 & 21 \\
\hline 1.38 & 61.2 & 1.14 & 0.64 & 22 \\
\hline \multirow[t]{2}{*}{1.62} & 66.6 & 1.08 & 0.38 & 14 \\
\hline & \multicolumn{3}{|c|}{ アプリケータロール下塗り, 総塗工量 $18.5 \mathrm{~g} / \mathrm{m}^{2}$} & \\
\hline 0.55 & 56.3 & 1.26 & 1.22 & 21 \\
\hline 0.91 & 56.5 & 1.26 & 0.85 & 20.5 \\
\hline \multirow[t]{2}{*}{1.14} & 56.5 & 1.26 & 0.85 & 15 \\
\hline & \multicolumn{3}{|c|}{ ショートドウェル下塗り, 総塗工量 $16 \mathrm{~g} / \mathrm{m}^{2}$} & \\
\hline 0.58 & 56.0 & 1.28 & 1.41 & 14 \\
\hline 0.76 & 53.5 & 1.45 & 1.33 & 8.5 \\
\hline 1.36 & 59.9 & 1.00 & 0.51 & 4 \\
\hline
\end{tabular}

* 低い数值は均一性が高いことを示す。 


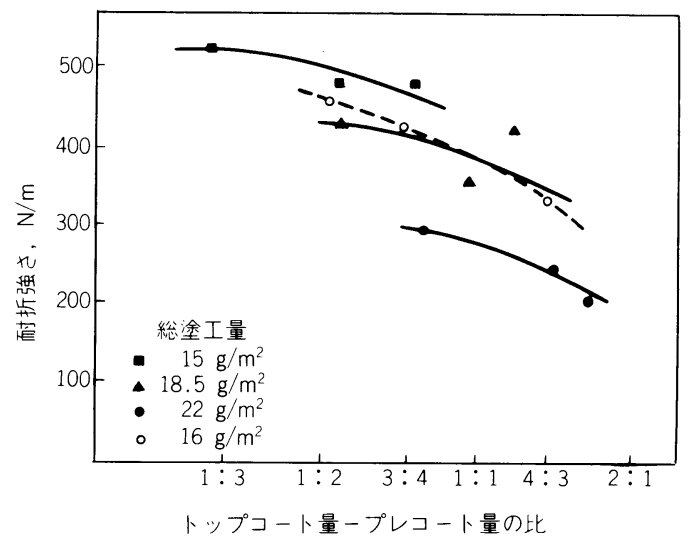

図 1 トップコート量とプレコート量の比が塗 層割れの傾向に与える影響（白抜きは ショートドウェル塗工，塗りつぶしはア プリケータロール塗工)

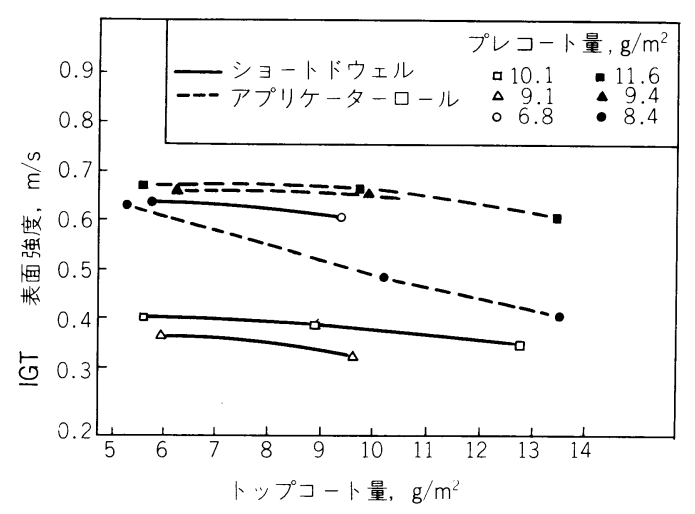

図 2 トップコート量及びショートドウェル方 式とアプリケータロール方式により塗工 のプレコート量が IGT 表面強度に与え る影響

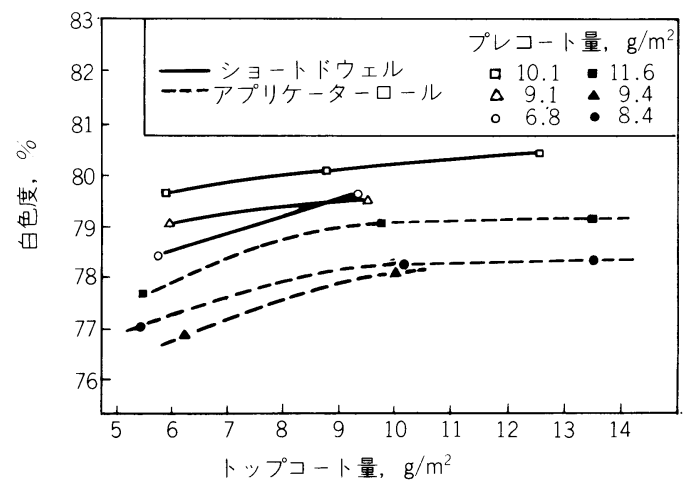

图 3 トップコート量及びショートドウェル方 式とアプリケータロール方式により塗工 のプレコート量が白色度に与える影響
図 2 に示す通り, IGT 表面強さに対するトップコー 卜量の影響は相対的に僅かであり，プレコート量と塗 工方法による影響の方が大きかった。特にショートド ウェル式コー夕を使用した場合は，プレコート量を低 く押えると，相対的に高い表面強さが得られた。これ はトップコートがプレコートに浸透し, 直接繊維層に 定着できたためである。

図 3 に示すとおり, プレコート量, トップコート量 共, 2 層塗工紙の白色度に影響を及ほす。プレコート 量が $9.5 \mathrm{~g} / \mathrm{m}^{2}$ を上回ると白色度は高くなる。トップ コート量が増加しても白色度は増加するが, $10 \mathrm{~g} / \mathrm{m}^{2}$ 以上ではほとんど増加しない。白色度はプレコート量 を多くして約 $10 \mathrm{~g} / \mathrm{m}^{2}$ のトップコートをした場合に 最高となった。

\section{4. 異なる塗工法の効果}

ショートドウェル式とアプリケーターロール式塗工 法が紙の特性にどのような影響を与えるかを評価する ため, 両方式を使用してプレコートとトップコートに 対してテストを実施した。ショートドウェル式コータ では原紙へ水とカラーが深く浸透しないので, 紙匹の 断紙が少なく走行性が良くなるものと考えられる。

1）プレコートテスト

プレコートに使用した場合, ショートドウェル方式 では, 表面強度が充分な強さになるほどバインダが原 紙に浸透しない。但しプレコート量が $6.8 \mathrm{~g} / \mathrm{m}^{2}$ と少 ない場合には, トップコートのバインダは繊維層まで プレコート層を通じて浸透し, 図 2 に示す通り表面強 さは向上した。

プレコート用にショートドウェル方式が使用された 場合, 白色度が向上する (図 3 )。その理由は塗工顔料 が原紙に深く浸透しなかったためと考えられる（白色 度はカラーの浸透度が向上しカラーの結合強度が向上 して光散乱性が低下することによって減少する)。

紙表面への付着性がよくなった結果と思われるが, ショートドウェル式の場合, 表面の均一性, 光沢と平 滑度がいくらか良くなった（表 3 )。

ロールアプリケータのニップにより原紙表面が湿潤 にされ, 纎維は著しく膨潤される。この現象はブレー ドの前側で顕著に発生しブレード通過後は少なくなる。 アプリケータロール部のニップ圧力によりカラーが原 紙に浸透し原紙への塗工層の定着性は改善されるが, 顔料の一部が原紙内に浸透することにより白色度が低 下する。

ショートドウェル式コータに比べ幅方向の塗工プロ ファイルは均一となる。表面強さは顔料とバインダの 
原紙の繊維層への浸透量に左右されるので，アプリ ケータロールをプレコートに使用することにより表面 強さは向上し, 塗層割れの傾向もやや減少した（図 1)。

\section{2）トップコーティングテスト}

図 4 に示す通り，アプリケータロール方式をトップ コートに使用した場合, ショートドウェル式コータに 比べ光沢は良くなった。従って MWC 紙のトップコー 卜用として適切な方式であると考えられる。これはア プリケータロール方式のニップ部での浸透圧力とド ウェルタイムが長いことによりドクタリングされる前 にプレコート紙の不均一部分がカラーで埋められ, 光 沢と平滑度が向上したものと考えられる。原紙の場合 ほど著しくはないが，メタリング前にプレコート面が 膨潤してしまうことも上記の改善に寄与しているもの と考えられる。アプリケータロールを使用すれば，高 塗工量でも容易に塗工出来る。一方，光拡散表面をい くらか失うことによってアプリケータロール方式では 白色度が約 0.5 程度低下寸る。

トップコート層をプレコート層により効果的に定着 させることにより，ショートドウェル方式に比べてよ り優れた表面強さが得られるものと期待されたが, 上 記のテストには当てはまらなかった。表面強さはトッ プコート塗工方法とは無関係で，プレコート層とトッ プコート層間の結合強度よりも原紙とプレコート層間 の結合強度の影響の方が大きいためと考えられる。

\section{5. 乾燥の最適化}

中質コート紙用として最適な乾燥工程を見出すため にいくつかの研究が行われた。色々な発見がなされた 中で, 乾燥方法が LWC 紙のモットリングに強く影響 していることが判明した。最近では 2 層塗工された中

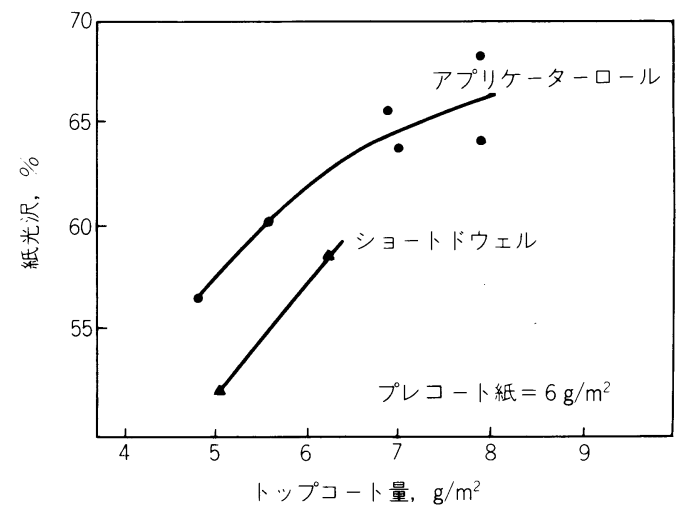

図 4 トップコート量と塗工方式が光沢に与え る影響
質コート紙に対する乾燥の方法の研究も行われている。

\section{1）プレコート乾燥テスト}

プレコート乾燥テストにおいては, 低粘度のスター チをバインダとして用い, ショートドウェルにより塗 工された場合, 紙の光沢と平滑度は赤外線乾燥により 強い影響を受けた。一方, 中程度の粘性のス夕ーチを バインダとして配合した場合，又はアプリケータロー ルで塗工した場合には, 光沢と平滑度は乾燥方式によ る影響をほとんど受けなかった。図 5，6に赤外線の 強度が光沢と平滑度に対しどのように影響するかを示 す。低粘性を持つスターチによるバインダを使用し, ショートドウェル方式で塗工される場合, $400 \mathrm{~kW} / \mathrm{m}$ 迄赤外線を強化すると 2 層塗工されスーパーカレンダ 掛された紙の光沢と平滑度は減少する。但しこの限度 を越えて赤外線を更に強化させると, 光沢と平滑度は 再び増加する。これは原紙への赤外線吸収性が 400 $\mathrm{kW} / \mathrm{m}$ の遷移点にて最大になるためである。これらの 条件下では紙の光沢はエアードライヤの温度と空気流 速によっても影響を受ける。

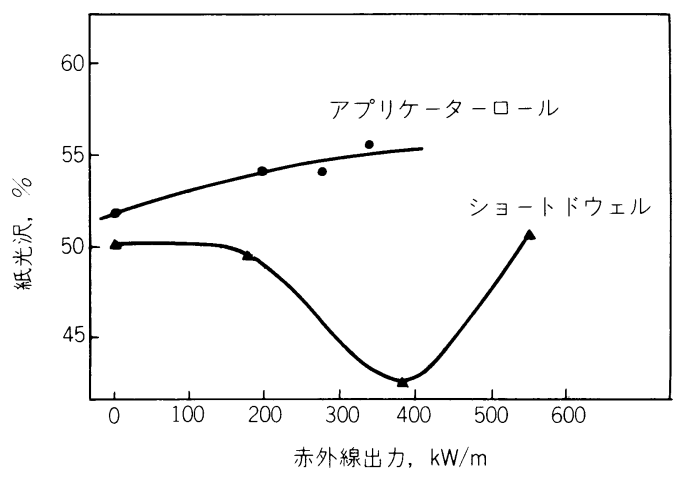

図 5 赤外線乾燥とプレコート方式が光沢に与 える影響

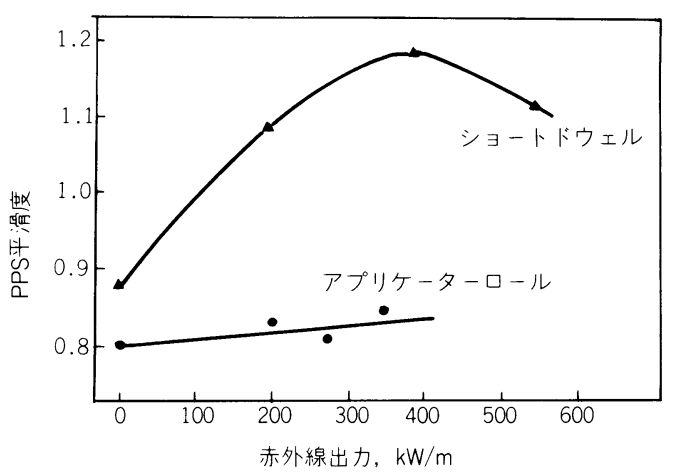

図 6 赤外線乾燥とプレコート方式が平滑度に 与える影響 
ブレード後の 2 基のエアーフォイルドライヤの蒸発 率を低く設定することにより，高蒸発量にて乾燥した ときに比べて最高 7 ポイント光沢が増加した。高粘性 のスターチを使用した場合には，上記とおなじ現象は 認められず，乾燥方式による影響は受けにくいことを 示している。2 層塗工された最終製品の印刷の見た目 と均一性（モットリング表示のための染料を使用して 測定）は乾燥方式及びスターチの粘性の変化とはあま り関係しない。

$$
\text { アプリケータロールによってプレコートした場合, }
$$

乾燥方式の変更により紙の光沢ないしは印刷光沢は大 きな影響は受けず，平滑度にも影響はなかった。その 理由はアプリケータロールを使用した場合，プレコー トに伴う纎維膨潤の大部分がブレード前に生じるので, ブレード後の塗工厚みがより均一になり乾燥方式によ る影響を受けにくいためである。しかしエアーフォイ ルで強く乾燥したり高強度の赤外線で乾燥した場合は 2 層塗工後の製品にやや多めのモットリングが生じた。 図 5，6に示す通り，原紙坪量及びトップコート量が 高い場合，ロールアプリケータでプレコートされた紙 は高い光沢と平滑度を示す。

白色度, 不透明度, IGT, 表面強さ, インキ濃度及び 塗層割れの傾向等は乾燥方式による影響をうけなかっ た。総論として, プレコートの乾燥方式のテストを通 して乾燥方法を変更しても, オフセット輪転機用中質 系 MWC 紙の品質に大きな影響を与えないことが判 明した。従ってプレコート後のドライヤの最適化をは かるに当っては, 品質上の問題点より乾燥能力やコス トの低減に考虑を払うべきである。

\section{2) トップコート乾燥テスト}

トップコートの乾燥テストでは様々な方法による乾 燥後, Crodaインキでサンプルを着色し目視評価を 行った。赤外線の強度を上げてゆくと $500 \mathrm{~kW} / \mathrm{m}$ まで は, 図 7 に示すようにモットリングは增加した。この レベルを越えると赤外線の強度を上げることによりよ り均一な表面が得られた。図 8 に示す通り,エアーフォ イルでも蒸発量を高くすると多くのモットリングが生 じた。トップコートの乾燥に関しては近い将来, 更に 詳細な研究を実施する予定である。

\section{6. コータのコンセプト}

4 基のブレードコータによる MWC 紙の生産方法 としては下記の 3 種類の方法が考えられる。

(1) 4 ステーション付オフマシンコー夕

(2) 2 ステーション付オンマシンコータ及びオフマ シンコータ 各 1 台

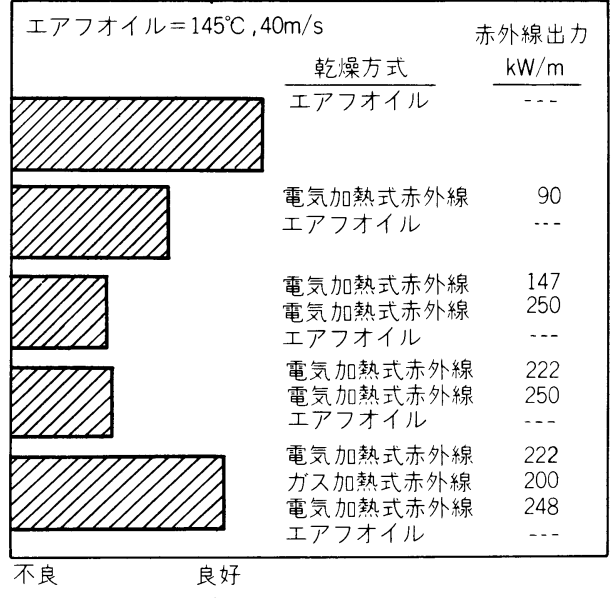

目視による均一性

图 7 トップコートにおける赤外線が目視の モットリングに与える影響

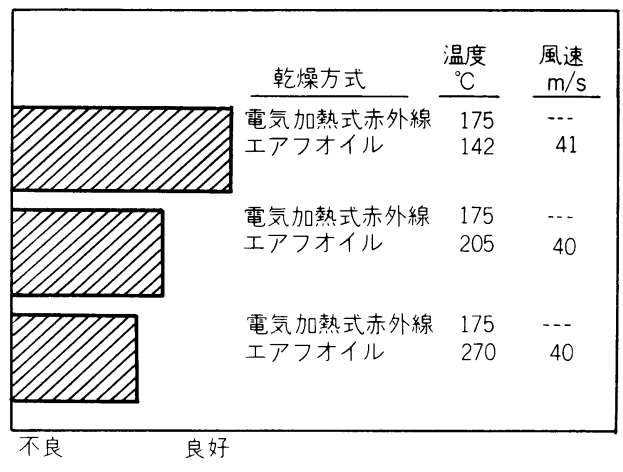

目視による均一性

図８トップコートの最初のエアオイルで蒸発 率が目視のモットリングに与える影響

(3) 2 ステーション付オフマシンコータ 2 台

1） 4 ステーション付オフマシンコータ

2 層塗工 MWC 紙を効率的に生産するには, ブレー ド式 4 ステーションを持つオフマシンコータが理想的 である。オフマシン方式は同一マシンで非塗工紙及び 塗工紙の両方を生産しなければならない場合に理想的 である。

一方，この方式で 1 層塗工紙を生産するのは複雑す ぎて適当でない。またこの方式ではコータの走行性が 優れていることと, 原紙の欠陥が最小限度であること が条件となる。コータでの断紙が抄紙機に影響を与え ない場合であっても，コー夕の稼働率は断紙や停止に よって激減する。 
2） 2 ステーション付オンマシンコータと 2 ステー ション付オフマシンコータ

2 ステーション付オンマシンコータと 2 ステーショ ン付オフマシンコー夕の組み合せは，4 ステーション 付オフマシンコータに比へ，特に 1 層塗工紙の生産に おいてフレキシビリティに富んでいる。同時にオぺ レー夕も少なくてすむ。しかし，この方式ではオンマ シン塗工に挑戦しなければならない。

プレコータでの断紙は抄紙機全体に影響を及ぼすの で, 高効率を得るには優れた走行性と原紙の欠陥が最 小限であることが不可欠である。プレコート紙の紙匹 欠陥は, トップコート前にリリーラーで取り除くこと が出来るのでオフマシンコータでの断紙の危険性は比 較的少ない。このオンマシンとオフマシンコータの組 み合せは， 1 層塗工紙と 2 層塗工紙の両方を生産する のに最も問題の少ない方法である。但し非塗工紙を生 産するには, オンマシンコータを含まない方式に比べ て複雑である。

\section{3）オフマシンコータ 2 基}

紙の走行性に問題がある場合，オフマシンコータを 2 基使用するのが有利な方法である。抄紙機後とプレ コート後に紙匹の欠陥をリリーラーで取り除くことが 出来る。この方式を用いることでトップ塗工時の走行 性の向上が期待される。どちらのコータの断紙も抄紙 機又は一方のコータの稼働率に影響を及ぼすことはな い。

非塗工紙， 1 層塗工紙及び 2 層塗工紙等を生産する 場合に，この方式により最大のフレキシビリティを得 ることができる。他の方式に比べ投資額とオペレータ の人数は多くなる。

なお，より集約された方式に比へ，連続運転中の損 紙量は多くなるが，フレキシビリティと走行性が重要 視される場合にはこの方式を採用することになろう。 走行性に問題を生じやすい強度の低い紙を生産するの には特に適している。

7. おわりに

1 層塗工に比べ 2 層塗工は明らかに印刷後も均一性 を保つ品質上の利点がある。2 層塗工は塗工に必要な
構成要素のトータルコストを下げる場合もある。

特に塗工量が多い場合, 総塗工量一定のときトップ コート量を増加させることにより, 紙の光沢と平滑性 が改善される。白色度はトップコート量約 $10 \mathrm{~g} / \mathrm{m}^{2}$ と プレコート量 $9.5 / \mathrm{m}^{2}$ 以上の塗工で最高になる。プレ コート用にロールアプリケータを使用することにより， 表面強さと塗層割れ抵抗が向上する。プレコート用に ショートドウェル式コータを使用することにより白色 度は向上し, 光沢, 平滑度及び紙表面の均一性もある 程度向上する。プレコートにショートドウェル式コー 夕を採用すれば, 走行性とコー夕の稼働率をより高め ることが出来る。

アプリケータロールによりプレコートする場合, プ レコートの乾燥方式による光沢と平滑度への影響はほ とんどない。ショートドウェル式コータによりプレ コートする場合, 紙の光沢は郝外線ドライヤの出力レ ベルとエアーフォイルドライヤの温度と空気流速によ る影響を受けるが，印刷後の紙の見た目の美しさと均 一性は乾燥方式の影響を受けない。スターチの粘度が 大きいことも乾燥方式の影響を低下させ, 粘度が小さ いと影響は目立って増大する。プレコート乾燥方式は 中質, ウエブオフセット MWC 紙の品質には大きな影 響を与えない。従って MWC 紙についてプレコート乾 燥の選択を行う場合, 品質上の問題よりも乾燥能力と 経済性の考慮を優先させることが出来る。トップコー 卜乾燥方式を選択する場合は品質に対する考慮がより 重要である。

トップコート用としてロールアプリケータを使用す ると，ショートドウェルの使用に比べ光沢は向上する。 またロールアプリケータの使用はショートドウェルの 使用による塗工量の増加に伴う問題を解消寸る。フレ キシビリティ及び走行性からみれば，オフマシンコー 夕 2 基を備えた生産ラインが MWC 紙用としては最 適な方式である。

この方式は投資額が大きくなるので，他の方式につ いても考虑する必要がある。各方式の中から 1 つの方 式を選定する場合, 生産の対象となる紙のグレードと 品種が決定要因となるであろう。 